\title{
Article
}

\section{A Proposal for the Effective Implementation of the Protective Mandate of the African Commission on Human and Peoples' Rights}

\author{
Uwazuruike, Allwell Raphael \\ Available at https://clok.uclan.ac.uk/29178/ \\ Uwazuruike, Allwell Raphael orcid iconORCID: 0000-0002-3746-9254 (2018) A \\ Proposal for the Effective Implementation of the Protective Mandate of the \\ African Commission on Human and Peoples' Rights. African Journal of Legal \\ Studies, 11 (2-3). pp. 178-200. ISSN 2210-9730
}

It is advisable to refer to the publisher's version if you intend to cite from the work. http://dx.doi.org/10.1163/17087384-12340032

For more information about UCLan's research in this area go to http://www.uclan.ac.uk/researchgroups/ and search for <name of research Group>.

For information about Research generally at UCLan please go to http://www.uclan.ac.uk/research/

All outputs in CLoK are protected by Intellectual Property Rights law, including Copyright law. Copyright, IPR and Moral Rights for the works on this site are retained by the individual authors and/or other copyright owners. Terms and conditions for use of this material are defined in the policies page.

\section{CLoK}

Central Lancashire online Knowledge www.clok.uclan.ac.uk

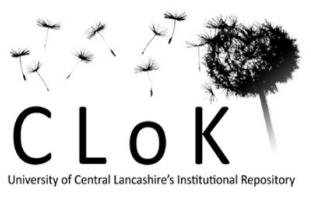




\section{A Proposal for the Effective Implementation of the Protective Mandate of the African Commission on Human and Peoples' Rights}

Allwell Uwazuruike ${ }^{1}$

\section{ABSTRACT}

The African Charter on Human and Peoples' Rights ushered in an era of human rights promotion and protection at the regional level. However, the African Commission, created for this purpose, continues to face challenges especially with regard to the protection of human rights. This article critically examines one of the core obstacles to the effective operation of the Commission's protective mandate - the binding nature of its recommendations - and formulates a proposal for bypassing that obstacle. It argues for the strengthening of the Commission's protective mandate through a distinct and unambivalent adoption of the Commission's rulings as official decisions of the AU Assembly backed by the concomitant full sanctioning power of the latter. Such adoption, it is argued, must go beyond the current near ceremonious practice whereby the Assembly receives and 'adopts' the Commission's Activity Reports and focus on the recommendations themselves. Adopting this new system, it is argued, will strengthen and add meaning to the Commission's protective mandate and further project the status of human rights across the continent.

Keywords: Africa, Human rights, African Commission, Reforms, Sanctions

\section{INTRODUCTION}

In June 1981 the Organisation of African Unity (OAU) adopted the African Charter on Human and Peoples' Rights ('African Charter') following years of egregious human rights violations in the continent by a few brutal and oppressive regimes. The Charter not only set out normative human rights principles for the continent but also created an institutional framework for monitoring and promoting compliance with these norms. This institutional framework came in the form of the African Commission on Human and Peoples' Rights ('African Commission' or 'Commission')2. After more than three decades of operation of the African Commission,

${ }^{1}$ Lecturer in Law.

${ }^{2}$ This was followed, several years later, by the creation of an African Court. 
pertinent questions subsist as to whether it has met its duty of protecting human rights as envisaged by the Charter. Perhaps even more pertinent is the question of how the challenges confronting the implementation of its protective mandate can be adequately addressed.

\section{THE PROTECTIVE MANDATE OF THE AFRICAN COMMISSION}

The bulk of the Charter's provisions on communications is dedicated to interstate communications. However, states have barely put the system to use with only one interstate communication $^{3}$ completed with the decision given after the matter had been substantially resolved. ${ }^{4}$ Even though the Charter does not expressly state so, individuals and NGOs can make complaints to the Commission under Article 55 which provides for 'communications other than those of state parties.' It appears that, as part of the bid to facilitate ratification, the drafters of the Charter avoided stressing the individual's role in the communications process. However, this was the interpretation clearly adopted in Rule 93 of the Commission's 2010 Rules of Procedure. The said provision in stipulating guidelines for communications brought under that heading makes reference to the "name, nationality and signature of the person or persons filing it; or in cases where the Complainant is a non-governmental entity, the name and signature of its legal representative." ${ }^{5}$ It is this group of communications that forms the fulcrum of the present analysis.

Communications from individuals and NGOs would need to pass admissibility tests based on the decision of a simple majority of members of the Commission. Some conditions that need to be met include compatibility with the African Charter and exhaustion of public remedies. ${ }^{6}$ The Charter is largely silent on what happens after individual communications have been considered. Cues can, however, be taken from the provisions regarding state communications as well as Article 58 relating to special cases of serious or massive violations. With regard to the latter, the Charter provides that the Assembly of Heads of State and Government ('the Assembly') may request the Commission to undertake an in-depth study of such cases and make a factual report accompanied by its findings and recommendations. Similarly, on state communications, the Charter provides that the Commission may, while

${ }^{3}$ Democratic Republic of Congo v Burundi, Rwanda, Uganda Communication 227/99.

${ }^{4}$ F Viljoen, 'Communications under the African Charter: Procedure and Admissibility' in Malcolm Evans and Rachel Murray (eds) The African Charter on Human and Peoples' Rights: the System in Practice 1986-2006 (2nd edition Cambridge University Press, Cambridge 2008) 137.

${ }^{5}$ R $952(\mathrm{~A})$.

${ }^{6}$ Art 56. Other requirements are that the communications indicate their authors, not written in disparaging language and not based exclusively on news disseminated by the media. 
transmitting its report to the Assembly, make 'such recommendations as it deems useful. ${ }^{.7}$ Both of these provisions appear to limit the Commission's role in the communications process to writing reports and making recommendations to the Assembly. Furthermore, all measures taken under the Charter are to remain confidential until the Assembly decides otherwise. ${ }^{8}$

\subsection{The Nature of Recommendations: Binding or Not?}

Perhaps one of the most controversial issues relating to the Commission's protective mandate is on the nature of its decisions and whether they are binding on states against whom they are made. The earliest views coming after the drafting of the Charter was that the Commission's decisions did not have binding force. ${ }^{9}$ These arguments were based on the language of the Charter and the general disregard by member states of final decisions of the Commission. It was argued that the Commission, as structured and mandated under the Charter, was merely a committee making recommendations to the Assembly of Heads of State and Government. It was seen as largely ineffectual ${ }^{10}$ with its recommendations merely 'urging' states to comply with its directives. ${ }^{11}$ Thus, in the words of one writer, "the Charter remedy [was] ineffective and there [was] in fact, no remedy within the Charter." 12 This view continues to be held by some commentators. ${ }^{13}$ However, it appears that scholars are now more willing to accept the Commission's 'progressive' interpretation of its protective mandate - that is that its decisions become binding after the adoption of its Activity Reports by the AU Executive Council. ${ }^{14}$

It is interesting to note that many of these scholars place emphasis on the nature of the Commission and, by extension, its rulings in deciding the effectiveness of its protective mandate. This, of course, feeds into the longstanding debate of whether the nature of a body, judicial or quasi-judicial, delivering a ruling, has any impact or bearing on states' implementation of that ruling. For instance, somewhat in contrast to the positions above,

${ }^{7}$ Art 53.

${ }^{9}$ See O Okere, 'The Protection of Human Rights in Africa and the African Charter on Human and Peoples' Rights: A Comparative Analysis with the European and American Systems' (1984) 2 Human Rights Quarterly 141; M Mutua, 'The African Human Rights Court: A Twolegged Stool?' (1999) 29 HRQ 342; C Heyns, 'African Regional Human Rights System: The African Charter' (2003) 108 Pennsylvania State law Review 679; Vincent Nmehielle, 'Toward an African Court of Human Rights: Structuring and the Court'(2000) 6 Annual Survey of International and Comparative Law 27; Frans Viljoen, 'A Human Rights Court for Africa, and Africans' (2004) 30 Brooklyn Journal of International Law 1.

${ }^{10}$ Mutua (n 4) 351.

${ }_{11}^{11}$ Heyns (n 4) 698.

${ }_{13}^{12}$ Nmehielle (n 4) 39. system' (2016) 9(1) Journal of Pan African Studies 221 . system' (2016) 9(1) Journal of Pan African Studies 221

${ }^{14}$ See for instance, F Viljoen, 'Impact in the African and Inter-American Human Rights Systems: A Perspective on the Possibilities and Challenges of Cross-Regional Comparison' In P Engstrom (ed.) The Inter-American Human Rights System (Springer 2018) 303-326; F Viljoen and L Louw 'The Status of the findings of the African Commission: from moral persuasion to legal obligation' (2004) 48(1) Journal of African Law 1-22. 
Murray and Long are of the opinion that, whilst not totally lacking in relevance, the nature of the institution (or, in this case, the African Commission) is a "useful but unwelcome distraction." 15 They argue that while there is evidence that suggests an increase in the rate of compliance where there is a "binding" ruling, such an increase is 'not significantly' higher than those of non-judicial bodies. ${ }^{16}$ They state that political factors such as drafting and sense of ownership of the relevant document (in this case the Charter) and quality of the finding were important in influencing compliance. Interestingly, and in what could no doubt be a significant support for the approach suggested in this article, they find that the "more conclusive and determinative" factor "is the respect which the body is accorded" by states and other stakeholders. ${ }^{17}$

The argument for the role of political and legal factors in whether states comply with the Commission's decision is certainly a reasonable one. However, it is clear, even conceded by the authors, that the apparent lack of binding authority certainly plays a useful, if not integral, role in this state of affairs. It has even, for instance, been noted that the Commission's lack of binding authority is the most cited reason for states' non-compliance with the Commission's decisions on communications. ${ }^{18}$ Granted that labelling the Commission's decisions as binding may not necessarily result in total or overwhelming compliance by states, it is logical to assume that any ambiguity on its status can only have a negative impact on state compliance.

In the following sections, this article will examine the general approach of member states and the Commission to the latter's rulings. It will be shown that both sides have, by words or implication, attached importance to the binding nature of the Commission's decisions - states (or, at least, some of them) in their occasional refusal to comply, and the Commission in their amended rules of procedure. The aim is to highlight the often-distinct approaches of both sides and the conceptual and practical flaws of the Commission's approach. Ultimately, and in keeping with previous findings, ${ }^{19}$ the article suggests an improvement to the Commission's approach through the more "respected" institution of the Assembly of Heads of state.

\footnotetext{
${ }^{15} \mathrm{R}$ Murray and D Long, The Implementation of the Findings of the African Commission on Human and Peoples' Rights (Cambridge University Press, 2015) 9.

${ }^{16}$ ibid 16

${ }^{17}$ Widid 24.

${ }^{19}$ E.g Murray and Long (n 15).
} 


\subsection{States' Response to Decisions of the Commission on Communications}

It would come as no surprise that states have not always shared the Commission's view on the binding nature of its decisions. Firstly, implementation of the Commission's decisions has generally remained low. ${ }^{20}$ Some of the more recent studies have put the rate of compliance at $15 \%,{ }^{21}$ a slight improvement on a previous figure of $12 \% .{ }^{22}$ These statistics show very little improvement from the rate of compliance in earlier studies. ${ }^{23}$ The general attitude of states, it has been pointed out, has been to ignore these recommendations, with no attendant consequences. ${ }^{24}$ In the Commission's own assessment, "member states generally do not comply with the decisions of the Commission or implement its recommendations." ${ }^{25}$ Even more seriously, some states have challenged the competence of the Commission to issue binding decisions. In the case of Good v. Botswana ${ }^{26}$ which involved the deportation of an Australian Professor in 2005, after he had co-authored an article concerning presidential succession in Botswana, the state (Botswana) in its response to a complaint brought before the African Commission challenged the latter's authority to issue binding decisions. Even after the Commission's finding in favour of Mr. Good, including an award of compensation, Botswana refused to comply. Botswana's Foreign Affairs Minister was quoted as saying:

"We are not going to follow the recommendation made by the Commission. It does not give orders, and it is not a court. We are not going to listen to them. We will not compensate Mr. Good."27

Such a clear and unapologetic rejection of the Commission's authority no doubt cast a huge shadow of doubt on its protective mandate. Interestingly, the AU Executive Council, in what

\footnotetext{
${ }^{20}$ The Commission itself notes this in its recent Activity Reports. See for instance, $43^{\text {rd }}$ Activity Report of the African Commission 2017; see also M Sssenyonjo, 'Responding to Human Right violations in Africa: Assessing the Role of the African Commission and Court on Human and Peoples' Rights 1987-2018' (2018)7 International Human Rights Law Review 20.

${ }^{21}$ Murray and Long (n 15).

${ }^{22}$ Seven cases of implementation out of 60 decisions finding states in violation) with cases of partial compliance at $34 \%$. See The Open Justice Initiative, From Judgment to Justice: Implementing International and Regional Human Rights Decisions

${ }_{23}$ Onttp://www.opensocietyfoundations.org/sites/default/files/from-judgment-to-justice-20101122.pdf $>$ accessed 15 March 2015 . partial compliance. See Viljoen and Louw (n 21).

${ }^{24}$ Wachira and Ayinla (n 23).

${ }^{24}$ Aachira and Ayinla (n 23). 33/achpr5152_actrep32and33_eng.pdf> EX.CL/782(XXII) Rev.2.

${ }^{26}$ Communication 313/05

${ }^{27}$ Simisani Chilisa, 'Botswana Will Not Honour African Union Ruling on Prof Good', 02/08/2010 Sunday Standard News (Botswana, 2 August, 2010).
} 
some may very well argue to be an endorsement of Botswana's stance, failed to take any concrete action after the Commission drew its attention to Botswana's non-compliance. ${ }^{28}$

Aside from final decisions of the Commission, states have also generally failed to comply with the Commission's requests for provisional measures. ${ }^{29}$ For instance, in the 1998 case of International Pen and Others (on behalf of Saro-Wiwa) v Nigeria ${ }^{30}$ the Commission called on Nigeria not to execute the complainant pending the final outcome of the communication before it. However, the government, in total disregard of the provisional measures issued, went on to execute the complainant. The Commission subsequently found that the death penalty imposed violated the African Charter.

It is, of course, important to avoid the trap of attributing non-compliance to a rejection of the Commission's binding authority. As Ssenyonjo correctly points out, with the exception of Botswana, most states have not "openly challenged" the legal status of the Commission's rulings. ${ }^{31}$ Researchers have identified factors such as lack of political will and absence of adequate follow-up mechanisms as contributing to states' non-compliance. ${ }^{32}$ However, it may be argued that some of these factors may yet be linked, directly or indirectly, to the binding nature of the Commission's decisions. For instance, it may arguably be more difficult to establish any legal or other basis for "follow-up" where such decisions are perceived as nonbinding. One may even further argue, building on the earlier point of "respect" for the body issuing the ruling, that states would have more respect for a body that is able to issue and enforce binding decisions. It is no surprise, therefore, that the Commission has adopted a firm stance with regards to the binding nature of its rulings.

\subsection{The Commission's Position}

It has already been pointed out that the Charter does not grant the Commission any express judicial authority under the communications procedure. By requiring the Commission to make recommendations to the Assembly, it appears that the final say on the steps to be taken in the aftermath of a communication largely rests with the Assembly. It is important to note here that the Assembly has since delegated this task of considering the Commission's reports to the

${ }_{29}^{28} \mathrm{~F}$ Viljoen (n 14).

${ }^{29}$ M Ssenyonjo (n 20) 21.

${ }^{30}$ Communications 137/94, 139/94, 154/96 and 161/97 (1998).

${ }^{31}$ M Ssenyonjo (n 20) 11.

${ }^{32}$ Wachira and Ayinla, Murray and Long 2015. 
Executive Council. ${ }^{33}$ Unfortunately, the Charter does not state what the Assembly, or Executive Council, should do after recommendations have been made and what effect, if any, would be given to these recommendations. Taking advantage of this loophole, the Commission has argued, not without some merit, that its decisions become binding after they have been adopted by the Executive Council after the latter's consideration of the Commission's Activity Reports. ${ }^{34}$ Given that the Commission's decisions are routinely adopted by the Executive Council, the practical implication is that they are binding on the states against whom they have been made. Supporting this stance, Viljoen and Louw argue that the "decision" of the Assembly (as the "parent" institution) to "adopt" the Commission's report and "authorise its publication" converts the latter's findings into legal decisions for which the Assembly takes "legal responsibility." ${ }^{35}$ While this position no doubt appears logical it is nonetheless contentious given, as already pointed out, the Charter's reticence on the issue. Such reticence is by no means limited to the Charter as the Assembly and, by extension, other AU political organs, have also failed to accord the requisite level of recognition to the Commission's rulings. Indeed, on the one occasion when the Commission reported Botswana unequivocal declaration of non-compliance, the AU Executive Council, aside formally noting the case, took no action whatsoever. ${ }^{36}$

It is necessary to point out that what the Assembly/Executive Council adopts is the Activity Report of the Commission which contains several matters aside from communications. ${ }^{37}$ Interestingly, the Commission is also no longer required to annex its decisions to the Activity Reports such that it is impossible to tell, from a mere reading of the report, what decision has been reached in a Communication. To impute to the AU organs the intention of adopting the particular decisions in each communication based on the mere adoption of the Activity Report is certainly optimistic and, given the region's political climate, arguably unrealistic. Such adoption, it is argued, is merely to make way for the publication of the report as envisaged under Article 59(3) of the Charter. ${ }^{38}$ Were the adoption of the report under the current regime of protection, to be "binding" as envisaged, there would have been little need for the subsequent creation of an African Court as it is clear that one of the chief

\footnotetext{
${ }^{33}$ See Frans Viljoen, Recent Developments in the African Regional Human Rights System (2004) 2 African Human Rights Law Journal $347 . \quad$ African Commission, Information Sheet No.3. Communication Procedure,

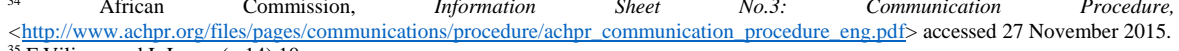
${ }^{35} \mathrm{~F}$ Viljoen and L Louw (n 14) 10.

${ }^{36} \mathrm{~F}$ Viljoen (n 14).

${ }^{37}$ The reports contain such information as the Commission's meetings and visits during the period reported.

${ }^{38}$ This article provides thus: 'The report on the activities of the Commission shall be published by its Chairman after it has been considered by the Assembly of Heads of State and Government.'
} 
reasons for the creation of such a court was the general perception of the non-binding nature of the Commission's decisions - whether adopted by the Assembly or not.

The Commission's position on the subsequent binding nature of its rulings is, therefore, tenable to the extent that the Charter intended for the Assembly to bestow binding character on such rulings. The Charter does not, however, state how this is to be done. Rather, it merely provides that reports on the activities of the Commission would be published only after they have been 'considered' by the Assembly. There is nothing to show that such publication or consideration would amount to bestowing binding force. The Commission's position and subsequent steps taken in furtherance of it (for instance through its new rules of procedure) may therefore, despite being progressive, not be in tandem with the spirit and intent of the Charter. For the Assembly's adoption to have such an effect it is argued, as will subsequently be demonstrated, that such adoption be clear, unambivalent, and specially enshrined in the Assembly's practices. Before moving on to consider this proposal, it is necessary to examine the Commission's position as demonstrated in its Rule of Procedures. The importance of such an examination is to demonstrate rudimentary inconsistencies in the Commission's approach and show how such an approach, despite being progressive, does not solve the intrinsic problems of the institution's protective mandate - and, ultimately, demonstrate the importance of a new approach.

\subsection{The Commission's Rules of Procedure}

No doubt influenced by its adopted position on the binding nature of its decisions, the Commission adopted, what was at the time, new rules of procedure which, amongst other issues, made provisions for following up on states' implementation of its decisions. By following up on the implementation of its decisions, the Commission would not only be keeping track of the steps taken towards implementation but also be applying pressure on states to implement its decisions. The approach of following up on the implementation of a decision necessarily implied that such decision is binding or, at least, should be enforced.

The provisions for revised follow-up procedures were no doubt influenced, at least in part, by a number of earlier studies on the effectiveness of such procedures in improving state compliance with decisions of the Commission. In one of such studies, Viljoen and Louw found that in four out of six cases of full compliance with the Commission's decisions, there had been some attempt by the Commission to follow up on the steps taken by parties to implement its 
recommendations. ${ }^{39}$ They concluded that as the Commission did not undertake any similar actions in the majority of 'noncompliant' cases, the issue of following up cases played a role in compliance. ${ }^{40}$ In another study, Wachira and Ayinla proposed the establishment of an institutionalised follow-up mechanism by the African Commission for the purpose of monitoring the implementation of its decisions and the issuance of specific recommendations. ${ }^{41}$ These propositions were obviously based on the proactive, albeit questionable, position that the Commission's decisions should become binding after the adoption of the Commission's Activity Report by the Assembly or Executive Council. Following this interpretation, Rule 112 of the Commission's amended Rules of Procedure provides for steps to be taken towards following up on the implementation of the Commission's decisions on communications including the appointment of a rapporteur to oversee such implementation. There have also been calls to "operationalise" the Permanent Representatives' Committee (PRC) subcommittee on human rights, democracy and governance which, inter alia, is to oversee the enforcement of the Commission's decisions. ${ }^{42}$

The presence of a flaw in the Commission's approach, as well as those of earlier researchers, is evident from the provision of Rule 118 of the said Rules of Procedure. This Rule provides for the Commission to submit a communication to the African Court where the Commission considers that the respondent state has not or is unwilling to comply with its recommendations in respect of the communication. Such submission to the Court, it is strongly argued, would be unnecessary were the Commission's decision to be binding as a decision of the Assembly. The appropriate body to take action in such an event would be the Assembly itself through warnings and sanctions. ${ }^{43}$ The provision for a-further referral to the Court only amounts to a concession on the binding nature of the Commission's ruling in the first instance. Furthermore, given, as will be demonstrated below, that decisions of the Assembly are accorded a relatively higher level of respect by member states there is little need for further judicial 'support' where a member state fails to comply with such a decision.

One can further argue that the Commission's approach is all the more questionable given the existence of the Court which was created to complement the protective mandate of

${ }^{39} \mathrm{~F}$ Viljoen and L Louw, 'State compliance with the recommendations of the African Commission on Human and Peoples' Rights, 19942004' (2007) American Journal of International Law 1.

${ }^{40}$ ibid 17

${ }^{41}$ G Wachira and A Ayinla, 'Twenty years of elusive enforcement of the recommendations of the African Commission on Human and

Peoples' Rights: a possible remedy' (2006) 6(2) African Human Rights Law Journal 465.

${ }^{42}$ See Executive Council Decision 1015 (2018).

${ }^{43}$ See relevant heading below. 
the Commission. It is no doubt difficult to sustain the argument for the existence of a 'complementary' judicial organ where the main body already issues binding decisions. The complications of this duplicationity become more obvious when one considers the apparent lack of synergy and coordination between the African Commission and Court. For instance, unlike other regional systems - the Inter-American and former European human rights systems - the African Commission performs both promotional and protective roles without any appellate or clear system of referral to the Court. These two bodies operate distinctly of themselves and with separate Rules of Procedure. Were its decisions to be binding upon the mere consideration of its Activity Reports by the Assembly, the Commission would not have any need to refer cases to the Court as the latter's only clear distinctive characteristic is its judicial nature demonstrated by its authority to pass 'binding' judgements. The creation of the Court would, therefore, amount to a mere duplication-two bodies delivering binding decisions both of which are to be enforced by the Assembly. ${ }^{44}$

In the light of the above, the following sections will propose ways for resolving, or at least, improving the protective mandate of the African regional human rights system. Such proposal is not merely conceptual but also necessary given that the Commission's newrevised rules have haddene little impact in the formway of improved state compliance. ${ }^{45}$ It will be argued that improved protection can be offered without deviating much from the spirit and wording of the African Charter-through a clear and unambiguous adoption of the Commission's recommendations as decisions of the Assembly of Heads of State and Government.

\section{THE ROLE OF THE AU ORGANS-ASSEMBLY AND EXECUTIVE COUNCIL}

This section seeks to make a relevant contribution to the discourse on the Commission's protective mandate by advocating a model that permits a clearer and useful involvement and participation of the AU Assembly. Of course, discourse on the role of the AU Assembly in contributing to the Commission's protective mandate, even though seldom analysed in any detail, is not by itself novel. However, this article approaches the issue from a perspective that has been paid little, if any, attention. The adopted position is generally hinged on three core foundations which have generally formed the basis of findings of previous research on the

${ }^{44}$ This argument is further expatiated in the relevant sections below.

${ }^{45}$ The Commission continues to lament the low compliance rate of member states in its Activity Reports. See for instance, the Commission's $42^{\text {nd }}$ and $43^{\text {rd }}$ Activity Reports. 
subject of the Commission's protective mandate. The first of such core principles is the need to adhere to the intent and spirit of the Charter in devising an alternative, albeit potentially more effective, approach. ${ }^{-46}$ The argument is that the Charter's approach of restricting the Commission to only issuing recommendations which would be given clear effect by the Assembly would ensure better respect and compliance with those recommendations. The second, as has been identified above by Murray and Long, is to the effect that one of the key factors that influences compliance is the respect attached to the institution that issues the decision issuing such a decision. The reasoning here is that the Assembly, as the principal organ of the AU, expectedly commands more respect and publicity than the Commission. ${ }^{47}$ The third is the need for a system effectively overseen by a body that has constantly demonstrated, as will be shown below, the willingness and ability to enforce its decisions through warnings and sanctions.

\subsection{The Assembly's Role under the Charter}

It has already been pointed out that the Charter, at least judging by its language and provisions, did not envision a Commission with judicial, or even, at least comprehensively, quasi-judicial powers. This is fostered by the Charter's use of words like 'finding' and 'recommendation' in reference to the Commission's 'decisions,' and the failure to make clear provisions for individual communications. ${ }^{48}$ Such current practices as hearing individual communications and facilitating compliance owe largely to the proactive interpretations and measures of the African Commission. However, this proactivity notwithstanding, it is clear that the Commission's protective mandate faces dire challenges some of which go to the root of the nature of its 'recommendations.' The argument, however, is that there may be little need of looking outside the Charter in order to remedy or, at least, ameliorate its arguably weak 'design' of the Commission. Quite on the contrary, it may even be argued that the Charter's approach, if effectively and proactively implemented, has clear potential to lead to a higher rate of compliance with the Commission's decisions. Put very simply, this would entail the Assembly adopting in very clear terms, and according to an established procedure, the recommendations of the Commission. It is conceded that this proposition is at variance with other analyses that

${ }^{46}$ A Uwazuruike, An Immanent Critique of the African Regional Human Rights System: Theory, Practice, and Reform (Doctoral

Dissertation, University of Central Lancashire 2017); R Murray and D Long (n 15).

${ }^{47}$ Murray and Long note the Commission's "lack of visibility" as one of its impediments; see Murray and Long (n 15) 25.

${ }^{48}$ Rather the Commission adopts the description 'Communications other than those of state parties.' 
argue or consider the Commission's findings as decisions of the Assembly in the context of the latter's adoption of the former's annual reports. It is argued, as will be demonstrated in the sections below, that a more proactive interpretation of the Charter could see the Assembly devise means of extricating and emphasising these decisions not as part of the annual reports but as separate decisions of the Assembly itself.

There is no doubt that the Assembly has an important role to play in the effective discharge of the Commission's protective mandate. This is largely due to the fact that the Commission is under the overall supervision of the Assembly, through the Executive Council, throughout the exercise of its protective mandate. Aside from submitting reports on state complaints ${ }^{49}$ and drawing the attention of the Assembly to the existence of massive violations of human rights, ${ }^{50}$ the Commission is also mandated to keep all of its measures confidential until otherwise decided by the Assembly. ${ }^{51}$ Going by these provisions, the Assembly is essentially the watchdog and enforcer of the Charter, or at least was so intended under the Charter. This is a point many commentators often overlook or do not pay sufficient attention to. While bemoaning the absence of real enforcement or binding power by the Commission, some of these commentators end up concluding that there is no remedy under the Charter. ${ }^{52}$

This, however, is not entirely correct. It is argued, from the language of the Charter, that it provides for the "possibility" of an effective remedy through the Assembly and, by extension, the Executive Council working on the reports and submissions of the Commission. It is important to point out that the situation would even not be very different were the Commission to be granted explicit powers to make binding decisions as the Assembly would, it is expected, still be the final port of recourse in the event that such decisions remained unimplemented. This is the case with the Court which, even though its decisions are "binding," is required to submit reports to the Assembly specifying the cases in which a state has not complied with its judgment. ${ }^{53}$ In the end still, the Assembly is expected to be the port of final recourse, at least in the case of the most recalcitrant and non-compliant states. In hindsight, the clamour that preceded the creation of a Court, therefore, becomes questionable especially when one considers that the court has been held back by the failure of states to ratify its protocol and make the declaration under Article 34(6) which allows for individual complaints against member states. The push, it is argued, should have been for greater and more streamlined

${ }_{51}^{51}$ Art 59.

${ }^{52}$ See for instance Nmehielle (n 4) 39.

${ }^{53}$ Art 31. 
participation of the AU Assembly and Executive Council in the Commission's communications and compliance process. There should have been a clamour for a system whereby the Assembly actively intervenes (as will later be demonstrated) in the aftermath of a communication, with direct bearing on the non-compliance of a member state with the decision of the commission. The creation of a court even though commendable amounted to an unwarranted duplicationity that tended to the symptom rather than the disease. Indeed, the Executive Council, in a rare acknowledgement of this duplicationity has, in a recent decision, ${ }^{54}$ directed the Commission to "address the ambiguity of its status" in relation to the Court.

It stands to reason, given the above analysis, that the Assembly can, through a direct adoption, remedy the defect (i.e. the non-binding nature) of the Commission's recommendation. Such an adoption has to be unambiguous and clearly intentioned. The requirement for clarity is important because of the unnecessary uncertainty that trails the mere adoption of Activity Reports which may be interpreted as only playing the Assembly's part in the Commission's duty of transmitting its report to it. As the intent is mainly to inform the Assembly of the Commission's activities, it becomes slightly presumptuous to expect that recommendations become binding by mere adoption of the Commission's activity reports. The Charter could not have gone through the rigours of describing the commission's decisions as recommendations and requiring them to be transmitted to the assembly, only for these recommendations to automatically become binding without any meaningful action or input on its part. One is then left with the question of what the need for such a transmission is. If the charter requires the commission to transmit recommendations to the Assembly or, as is the recent practice, the Executive Council, then it is reasonable to expect that the latter will acknowledge receipt. It is argued that the purported adoption and publication of the activity reports which include the recommendations is merely an exercise of the AU's supervisory role of the commission and is different from the "publication" envisaged under Rule 34 of the Assembly's Rules of Procedure (“Assembly’s Rules”). ${ }^{55}$ This position is justified from a cursory study of Article 59(2) and (3) of the Charter which provide for the publication by the "Chairman of the Commission" after it has been 'considered' by the Assembly. It is important to note the particular reference to the Chairman of the Commission thereby exempting the Assembly from the business of publication. Also worthy of note is the requirement for such chairman to only publish the report after it has been considered by the Assembly. The use of

${ }^{54}$ Executive Council Decision 1015 (2018).

${ }^{55} \mathrm{By}$ this rule, regulations and directives of the Assembly are to become automatically enforceable 30 days after the date of their publication in the official journal of the African Union or as specified in the decision. 
the word "considered" rather than "adopted," "ratified," or other similar words can hardly form the basis for the transmutation of such recommendations into final decisions of the Assembly. This is more so the case when one considers that other instruments (like the Assembly's Rules and AU Constitutive Act), when they use 'consider' in this context, always continue by showing that the Assembly would need to take a decision after such consideration. ${ }^{56}$ Even if, the above arguments notwithstanding, that it is the case, as currently practised, that the Assembly adopts the recommendations as its rulings, there is nothing to show, from the language of the Charter, that these should fall under the classification of regulations and directives as envisaged under Rule 33 of the Assembly's rules. ${ }^{57}$ From the wording, and apparent dillydallying of the Charter, it is more logical to group such adoptions under the heading of recommendations, declarations and resolutions which are not binding but intended to "guide and harmonise the viewpoints of member states". ${ }^{58}$

In order, therefore, for the adoption of the Commission's reports to serve as an endorsement or be elevated to the status of a decision of the Assembly, it has to be so clearly adopted as such-not merely as part of an activity report but as having transmogrified from a recommendation to a decision - in particular, a regulation or directive. In other words, there have to be such actions or procedures that show that the Assembly has accorded its imprimatur to that recommendation.

On this note, it becomes necessary for the Assembly to take extra steps to ensure clarity in its adopted position on the status of recommendations forwarded to it by the Commission. This would involve adopting the Commission's findings, not merely as part of the latter's Activities Report, but as decisions of the Assembly thereby making them legally binding. These could take the form of normal regulations and directives of the Assembly which would ordinarily be published in the official journal of the African Union. ${ }^{59}$ The added effect of this, apart from bestowing binding force, is that the Assembly will then be in a position to impose sanctions on defaulting states which would not have been possible with mere recommendations.

\subsection{The process of adoption}

\footnotetext{
${ }^{56}$ See for instance Rule 4(1)(o) of the AU Constitutive Act and Article 9 of its Rules which provide to the functions of the Assembly to include, inter alia, to 'receive, consider and take decisions' on reports and recommendations from the other organs of the Union.

${ }_{57}$ Rule 33 categorises decisions of the Assembly into: Regulations and directives (which are binding), and recommendations, declarations, ${ }^{57}$ Rule 33 categorises decision
etc. which are not binding.

${ }^{58}$ Rule 33(c).

${ }^{59}$ By Rule 34 of the Assembly's Rules of Procedure, regulations and directives become automatically enforceable 30 days after the date of their publication in the official journal of the African Union or as specified in the decision.
} 
The Assembly could adopt the final recommendations reached on communications in the same way it adopts and makes its official decisions. By Article 7 of the Constitutive Act of the AU ("Constitutive Act"), ${ }^{60}$ the Assembly is to take all its decisions by consensus or failing by a two-thirds majority of the member states eligible to vote. In passing its recommendation on a communication, the Commission should, in the spirit of Rule $19,{ }^{61}$ draft a 'ruling' in anticipation of the Assembly's adoption and forward it to the Executive Council. The Assembly is therefore to consider such 'ruling' and, one would expect, adopt it as a directive. Such directive would then be authenticated by the signature of the Chairperson of the Assembly and the Chairperson of the AU Commission ${ }^{62}$ and published in the official journal of the African Union. Overall, the decision-making process is expected to mirror the same level of authorship and ownership as other decisions, such as sanctions, of the Assembly.

\subsection{Imposition of sanctions}

The proposal for reform of the present system to make the Assembly responsible for imbuing binding force to the Commission's decisions stems largely from the Assembly's authority to impose sanctions. The importance of this ability can be gleaned from the Court's rules whereby, despite its clear judicial powers, the Court is still required to report back to the Assembly when a state fails to implement the Court's decision. ${ }^{63}$ It would therefore not be out of place to question parts of the Commission's new rules providing for recourse to the Court in cases of non-compliance. Given the Assembly's supervisory and 'adoptive' role it would be more efficient, in order to get states to comply with decisions, to get the Assembly to adopt those decisions through a clearly structured process.

Both the Constitutive Act and the Assembly's Rules contain similar provisions for when the Assembly can impose sanctions on erring member states. There are mainly three instances when this can be done. The first is where a state defaults in the payment of its contributions to the budget of the Union, ${ }^{64}$ the second is in the event of unconstitutional change of government; ${ }^{65}$ and the third is in instances of non-compliance with the Assembly's decisions and policies. ${ }^{66}$ Apparently, it is this last subdivision that would best serve the purpose

${ }^{60}$ Also Rule 18 of the AU Rules of Procedures.

${ }^{61}$ This rule provides thus: The text of all proposed decisions shall, upon recommendation by the Executive Council, be submitted in writing to the Assembly for consideration.

${ }^{62}$ Rule 32. It is important to note that the AU Commission in this case is not the same as the 'Commission' in the other parts of the article.

${ }^{63}$ Art 31 of the African Court Protocol.

${ }^{64}$ Art 23(1) and R 35(2).

${ }^{65}$ Art 30 and R 37 .

${ }^{66}$ Art 23(2) and R 36. 
canvassed in this article as the Assembly would need to adopt the Commission's recommendations as its decisions. The power of imposing sanctions of a 'political and economic nature' for non-compliance with decisions and policies of the AU is provided in the Constitutive Act ${ }^{67}$ with the Assembly's Rules ${ }^{68}$ highlighting the denial of transport and communication links as possible forms of sanctions. However, in what would, at first glance, appear to be a potential setback, the AU has hardly imposed any sanctions under the authority of this provision. ${ }^{69}$ This of course raises concerns as member states have, at least during the era of the AU's precursor, the Organisation of African Unity (OAU), been described as being in the habit of 'blatantly ignoring' the decisions adopted by OAU organs and rather adopting national policies which directly violated them. ${ }^{70}$ Such a state of affairs obviously does not bode well for the human rights system since it would appear that the very institution intended and portrayed (at least as canvassed in this article) as being able to attract binding force to the Commission's recommendations is unable to enforce them. It is therefore important to point out firstly that such 'blatant' dismissal by member states mainly characterised the era of the $\mathrm{OAU}$ - a body whose foundation was hinged on the principles of state sovereignty and noninterference. ${ }^{71}$ As will be briefly demonstrated below, the AU, through the Assembly, has shown clear resolve in imposing sanctions in certain situations and member states have generally made strong attempts to be in its good book. Interestingly, this resolve is more clearly seen in the other two subdivisions where sanctions are applied; viz, default in payment of contributions and instances of unconstitutional changes in government.

With regards to the first situation-state default in the payment of budgetary contributions-Rule 35 of the Assembly's Rules provides that the Assembly "shall” approve, following the Executive Council's recommendation, the imposition of sanctions where a state is found to have defaulted or is in arrears of payments. The possible sanctions vary depending on the extent of the breach. There are two levels based on whether the state is in arrears amounting to two years or more, but not exceeding five years, and whether the arrears amount to five years or more. With regards to the former, the prescribed sanctions seek to limit the defaulting state's participation within the AU. These include suspending the state's right to speak, vote and receive documentation at meetings of the AU, offer to host $\mathrm{AU}$ meetings, or

${ }^{69}$ In his 2011 paper, Magliveras notes that: 'It would appear that the Assembly has never imposed any sanctions on the authority of Article 23(2); see K Magliveras, 'The Sanctioning System of the African Union: Part Success, Part Failure?' (Institute of Security Studies Expert Roundtable on 'The African Union: The First Ten Years', Addis Ababa, October 2011) 8.

${ }^{70}$ ibid 3.

${ }^{71}$ See OAU Charter, Art III. 
present candidates for positions within the AU. ${ }^{72}$ The sanctions net appears to widen when the member state is in arrears for five years or more. Here, the Assembly may further suspend the member state's right to have the contracts of employment of its nationals renewed as well as withhold funds for projects in that state. The question that arises at this stage is whether and how the AU has invoked and implemented these sanctions. This is important because, as noted earlier, the OAU (which preceded the AU) owing to its sacrosanct non-interventionist stance did not do much to invoke sanctions against members that did not comply with its decisions. A similar attitude to all forms of infractions would, of course, paint the body a weak one incapable of imposing, let alone enforcing, sanctions. However, the opposite is the case. Being faced, at the time, with the challenge of non-payment of contributions, the OAU was forced to respond with sanctions against erring states. With little in the way of established provisions to go by, a new Rule ${ }^{73}$ was inserted in the OAU Financial Rules and Regulations to the effect that member states in arrears of contributions would not participate in OAU decisions and votes. ${ }^{74}$ Furthermore, in 1990, the Council of Ministers decided that such states would also be deprived of the right to speak at OAU meetings and to present candidates for OAU positions. These formed the basis for imposing sanctions on member states, such as Liberia, Somalia, Central African Republic, Seychelles, Democratic Republic of Congo, and Guinea-Bissau. A 'Credentials Committee' was even set up for the purpose of applying these sanctions. Such was the seriousness of enforcing these sanctions that some member states remained under long periods of sanctions despite prolonged internal crises in those states. ${ }^{75}$ The AU has, of course, followed in the OAU's footsteps of sanctioning members for arrears.

The aim here is not to assess the impact of sanctions in the payment of arrears but to show that the AU, where it is committed, can and does impose them. Of course, the issue of arrears in payment continues to plague the Union with the Assembly only allowed, under the Rules, to impose sanctions where arrears amount to two years or more. Also, it should be pointed out that, for many states, economic factors play a key role in defaults with most African states struggling with fragile economies and benefitting from foreign aid. ${ }^{76}$ These economic indices notwithstanding, the AU has, through the creation and application of sanctions for this category of violations, shown that it attaches a high level of seriousness to these infringements. 
It is this same level of seriousness and involvement that this article advocates in respect of the decisions of the Commission.

Another area that the AU has shown commitment through the application of sanctions is in cases of unconstitutional changes of government. By Rule 37 of the Assembly's Rules, the Assembly is to condemn such change and immediately suspend the member state from participating in the organs of the Union. The Assembly must also sanction the erring state where the regime fails to restore constitutional order. Possible sanctions include visa denials for perpetrators and trade restrictions. It is interesting that the language of the provisions does not leave room for discretion. Every violation is expected to be met with the same response, and the AU has, generally applied a good degree of consistency here. Sanctions have been imposed on states like Burkina Faso, Togo, Mauritania, ${ }^{77}$ Madagascar, ${ }^{78}$ Guinea, ${ }^{79}$ and, more recently, Egypt. ${ }^{80}$ The AU's Peace and Security Council, the standing decision-making organ for the prevention, management, and resolution of conflicts, has actively exercised its mandate in this regard.

\subsection{Sanctions in the context of the Commission's decisions}

The imposition of sanctions is certainly one way that the Assembly can improve the effectiveness of the Commission's decisions and, as has been argued above, this can be done if the Assembly takes the initiative of adopting them as AU decisions. States would no doubt fail to implement decisions, whether 'binding' or not, if they do not see any benefits of doing so or any repercussions by the way of sanctions or negative publicity. Arguing along this line, Viljoen states that the issue of the binding authority of the Commission's decisions is largely a red herring because compliance would ultimately depend on political factors such as the possible application of sanctions for non-compliance. ${ }^{81}$ What this article has done is to establish a basis and framework under which such sanctions can be imposed.

\footnotetext{
${ }^{77}$ In the case of Mauritania, the PSC called for the enforcement of an immediate travel ban on government officials. The AU also blocked the country's military government from attending its summit in Ethiopia. See VOA News, 'AU sanctions Mauritania' (2009)

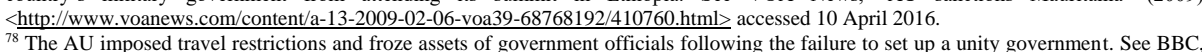
'African Union acts against Madagascar's Andry Rajoelina' (2010) < http://news.bbc.co.uk/1/hi/world/africa/8574051.stm> accessed 10 April 2016.

${ }^{79}$ The AU imposed travel bans and froze assets of Guinean officials. See BBC News, 'Sanctions imposed on Guinea Junta' (2009)

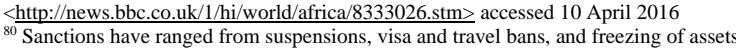

${ }^{81}$ See F Viljoen, International human rights law in Africa (Oxford University Press 2012) 340.
} 
The idea of the above narrative, on sanctions for arrears and unconstitutional changes in government, is that similar assertive steps can be taken in respect of recommendations of the Commission subsequently adopted as decisions of the Assembly. By ascribing the same level of importance to these decisions as to the above-above-discussed classes, the Assembly would be passing a strong positive message on the importance of human rights protection and enforcement. This would place the AU on a similar pedestal as the Council of Europe and European Union which place observance of human rights (including decisions of human rights bodies) as conditions for membership. ${ }^{82}$ Such a message would be stronger were the Assembly to adopt similar non-discretionary procedures ${ }^{83}$ as in the two classes discussed. This would mean that non-compliance with the Commission's decisions would be met by, at least, preliminary measures like warnings by the Assembly and subsequent measures if need be, as opposed to the present regime of silence and indifference.

Needless to state, the imposition of sanctions will not guarantee compliance by all states. It would, however, add meaning to the Commission's mandate as well as the Assembly's duty to monitor the decisions of the Union and ensure compliance by all member states. ${ }^{84}$ It is also important to point out that member states, have over the years, demonstrated their perceived respect and value to continued membership of the AU including the accompanying rights to vote in the Assembly and other organs. For instance, after its initial suspension from the AU following the undemocratic ousting of its president, Egypt, one of the continent's biggest economies, despite initial nonchalant posturing, "fought tooth and nail for its instatement to the AU." 85 This included "frantic diplomacy" and lobbying of AU member states as subsequent presidential elections were wrapped up - a process which eventually paid off with the country's readmission into the Union. ${ }^{86}$

Capturing the necessity for more meaningful intervention by AU political organ, Viljoen, in a recent comparative analysis of regional human rights systems, points out that weak political oversight within the African system is partly due to the "lack of a clearly workedout system of political oversight, well-defined guidelines and limited capacity." ${ }^{87}$ It is clear from the arguments above, that there is need for a more efficient system that mirrors the PSC and Credentials Committee in the two subdivisions above.

${ }^{82}$ For instance, the Statute of the Council of Europe empowers the Committee of Ministers to sanction non-compliant states by suspending or expelling them under Articles 3 and 8 .

${ }^{83}$ For instance, Article 23(1) of the AU Assembly Constitutive Act mandates the Assembly to impose sanctions on defaulting member states. Similarly, there is no political discretion in cases of unconstitutional takeover of government.

${ }_{84}^{\text {Similarly, there is no political } 23 \text { of the Constitutive Act. }}$

${ }^{84}$ Art 23 of the Constitutive Act.
${ }^{85}$ Dersson, 'Egypt vs African Union: A mutually unhappy ending?' 14 July 2014

$<$ https://www.aljazeera.com/indepth/opinion/2014/07/egypt-vs-african-union-mutually-u-2014714687899839.html〉 accessed 20 July 2018

${ }^{87} \mathrm{~F}$ Viljoen (n 14) 
On his part, Viljoen advocates the creation of a section dedicated to implementation in the AU Department of Political Affairs, as well as the inclusion of a standing item on "Implementation of human rights decisions" on the agenda of the PRC and Executive Committee. ${ }^{88}$ These suggestions very much support the analysis above in that, as has been shown for cases of arrears and unconstitutional changes in government, the enforcement of the Commission's decisions needs similar effective supervision at the level of the AU political organs. The current practice of treating and seeking to implement these decisions at the level of the Commission would, it is argued, continue to face political obstacles which that body is ill-equipped to deal with. Going further, he suggests that, the Commission is "as a matter of last resort" entitled to draw the attention of the AU's Sub-Committee of the Permanent Representatives Committee and the Executive Council on the Implementation of Decisions to instances of non-compliance. ${ }^{89}$ While this would be a practical solution in the context of the present rules, it is argued that it is an ineffective one. Aside from being used only sparingly, it has been shown that one such report failed to elicit any effective response from the Executive Council not least because of the ambiguity around the nature of such decisions and unclear rules on what should be done after such referrals or reports. A clear process of adoption by the Assembly, as canvassed in this article, would no doubt clear such conceptual and procedural doubts.

\section{CONCLUSION}

This article set out to address the relevant issue of the weakness of the African commission's protective mandate. It aimed to introduce an original perspective to the debate aimed at addressing the perceived defects and weakness of the institution's protective mandate. This importance of this analysis was highlighted by the general weakness of the African Court in the face of member states' unwillingness to make the declaration under Article 34(6) allowing individual and NGO access to the Court. Overall, and based on various analysis, it was concluded that, as opposed to the system currently adopted by the Commission, adherence to the wording and intent of the Charter has a better potential for improving compliance with the institution's decision and human rights implementation generally. The article started off by first establishing, contrary to the arguments of the Commission and other esteemed 
commentators, that the commission's recommendations, as envisaged under the Charter, are not binding. It argued that the basis for this position, the adoption of the Commission's Activity Reports, was impractical and went against the clear wording and intent of the Charter. Also, it sought to demonstrate the underlying weaknesses in what is, hitherto, thought to be a more practical and proactive position. These weaknesses are demonstrated in the clear lack of endorsement, by the AU political organs, of the Commission's adopted position and the dissonance generated by the unnecessary duplicity of human rights institutions within the African regional system. A potential solution to these weaknesses lies in the effective participation of the AU political organs headed, as envisaged by the Charter, by the Assembly. This participation would revolve around the specific and distinct adoption of each of the Commission's recommendations backed by the potential imposition of sanctions. In order to demonstrate the practicality of this approach, the article examined the AU's committed disposition to imposing sanctions in two instances namely, member states' arrears in payments and unconstitutional changes in government. The AU, it is proposed, would simply need to demonstrate similar political will towards the implementation of human rights on the continent.

This would be done through the activation of non-discretionary procedures, similar to the AU's response to unconstitutional changes of government, for adopting and enforcing the Commission's decisions. The adoption of such a procedure, it is believed, would be a significant first step to the development of human rights enforcement in the continent. 